Article

\title{
The Impact of the Coronavirus on Agriculture: First Evidence Based on Global Newspapers
}

\author{
Attila Jámbor ${ }^{1, *(\mathbb{D}}$, Péter Czine ${ }^{2}(\mathbb{D})$ and Péter Balogh ${ }^{2}$ (I) \\ 1 Department of Agricultural Economics and Rural Development, Corvinus University of Budapest, \\ Fôvám tér 8, 1093 Budapest, Hungary \\ 2 Department of Statistics and Methodology, University of Debrecen, Böszörményi út 138, \\ 4032 Debrecen, Hungary; czine.peter@econ.unideb.hu (P.C.); balogh.peter@econ.unideb.hu (P.B.) \\ * Correspondence: attila.jambor@uni-corvinus.hu
}

Received: 4 May 2020; Accepted: 26 May 2020; Published: 3 June 2020

\begin{abstract}
Since late 2019, an outbreak of the coronavirus disease 2019 (COVID-19) has rapidly spread all over the world, challenging the sustainability of global agri-food markets. Although its full impact on agricultural and food markets is not yet evident, we have some early evidence on the different impacts. The aim of this article is to summarize the early evidence by screening global newspaper articles and sites written on the topic until 10 April 2020. The most read English-based newspaper articles were downloaded and accessed together with a Google search on specific keywords in order to have a complete picture of the topic. Results suggest that agriculture-related pandemic effects can be grouped into supply, demand, labour, food security, food safety, trade and other effects. It is also evident that the first impacts are not one-sided: what helped some hurt others. This article can serve as a basis for future research on the topic by identifying and highlighting the key topics as well as summarizing the earliest evidence available.
\end{abstract}

Keywords: corona; virus; COVID; newspaper; agriculture

\section{Introduction}

Coronavirus disease 2019 (COVID-19) is continuing to spread around the world, causing hard times for many economies and sectors, including agriculture. The virus has posed serious challenges for the sustainable functioning of agri-food markets. As of 1 May 2020, more than 3.2 million cases were confirmed with over 231,000 deaths. The WHO is still reporting a continuous rise in the number of cases, with the pandemic now spreading to virtually all countries of the world. After the first shock, many newspapers have started to post articles on the different effects of the virus related to agriculture. Although understandably, the first articles were simply about the importance of staying home, more complex analyses of the different effects have become available as time has passed. The aim of this article is to provide a summary of these newspaper articles and see how this novel pandemic threat was depicted in global newspapers.

Although we lack enough long-term data to properly analyse its global sustainable impacts, the scientific community as well as industry stakeholders are seeking knowledge and information on the short- and long-term effects of the pandemic. Although the full impact of the virus on agriculture is not yet known, agriculture is in the spotlight as food is necessary for us to live, and is also related to the Sustainable Development Goals. This article can serve as a background for future research by setting the scene and highlighting the most important areas to analyse in the future when data become available. 


\section{Materials and Methods}

Our data collection process took place from 1 to 10 April 2020. The search process consisted of three steps (Table 1).

Table 1. The search process.

\begin{tabular}{|c|c|c|c|}
\hline Step 1 & & Step 2 & Step 3 \\
\hline Keywords of Search & $\begin{array}{l}\text { Results } \\
\text { (Number) }\end{array}$ & $\begin{array}{c}\text { Relevant Articles on the } \\
\text { Topic (Number) }\end{array}$ & $\begin{array}{c}\text { Analysed Articles } \\
\text { without Overlaps } \\
\text { (Number) }\end{array}$ \\
\hline $\begin{array}{c}\text { "corona + agri + name of } \\
\text { news site" }\end{array}$ & 767 & \multirow{4}{*}{$\begin{array}{c}\text { Based on "keywords }+ \\
\text { names of news site": } 118\end{array}$} & \multirow{4}{*}{$\begin{array}{c}\text { Based on "keywords }+ \\
\text { names of news site": } 118\end{array}$} \\
\hline $\begin{array}{l}\text { "corona + food + name } \\
\text { of news site" }\end{array}$ & 900 & & \\
\hline $\begin{array}{c}\text { "virus + agri + name of } \\
\text { news site" }\end{array}$ & 908 & & \\
\hline $\begin{array}{c}\text { "virus }+ \text { food }+ \text { name of } \\
\text { news site" }\end{array}$ & 819 & & \\
\hline "corona + agri + news" & 189 & \multirow{4}{*}{$\begin{array}{l}\text { Based on "keywords + } \\
\text { news": } 50\end{array}$} & \multirow{4}{*}{$\begin{array}{c}\text { Based on "keywords + } \\
\text { news": } 46\end{array}$} \\
\hline "corona + food + news" & 149 & & \\
\hline "virus + agri + news" & 218 & & \\
\hline "virus + food + news" & 179 & & \\
\hline Total & 4129 & 168 & 164 \\
\hline
\end{tabular}

Step 1: We used the Google search engine with eight different word pairs, and we got the following numbers of search results:

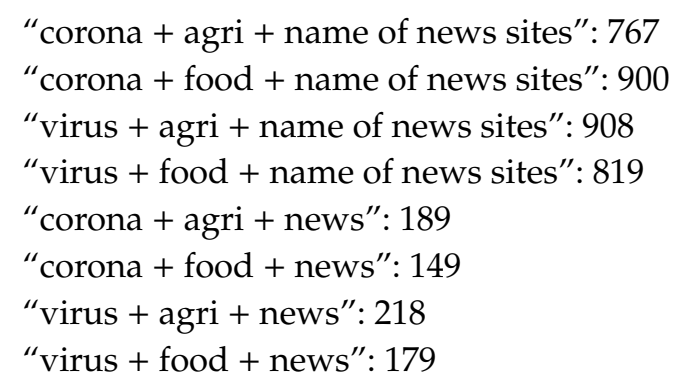

"Name of news sites" signifies the chosen online newspapers. When selecting the newspapers, we kept in mind that they should be English-language pages read by as many people as possible. This was based on a ranking of the 15 most-read news websites published in February 2020 [1]. Of these, the first two rated were not taken into account as they were simple search pages (Yahoo News, Google News) and redirected the search results to other news sites. Additionally, we did not work with websites that can only be viewed with a subscription (New York Times, Washington Post, Wall Street Journal). Finally, we were able to review nine news pages (CNN, NBC News, Huffington Post, Fox News, Daily Mail, The Guardian, ABC News, BBC News, USA Today).

Step 2: We chose relevant articles on the topic from the search results. The "keywords + names of news sites" searches resulted in 118 articles, while the "keywords + news" searches resulted in 50 articles.

Step 3: In the last step, we filtered overlaps. After this process we had 118 (“keywords + names of news sites") and 46 ("keywords + news") articles. Thus, a total of 164 articles were included in the analysis. 


\section{Results}

The distribution of papers by news pages is shown in Figure 1. A simple Google search for just those keywords resulted in 46 related articles (after eliminating overlaps). Figure 1 clearly shows that the news sites covered the topic to a similar extent, but an exceptionally high number of articles can be observed in the case of The Guardian news site.

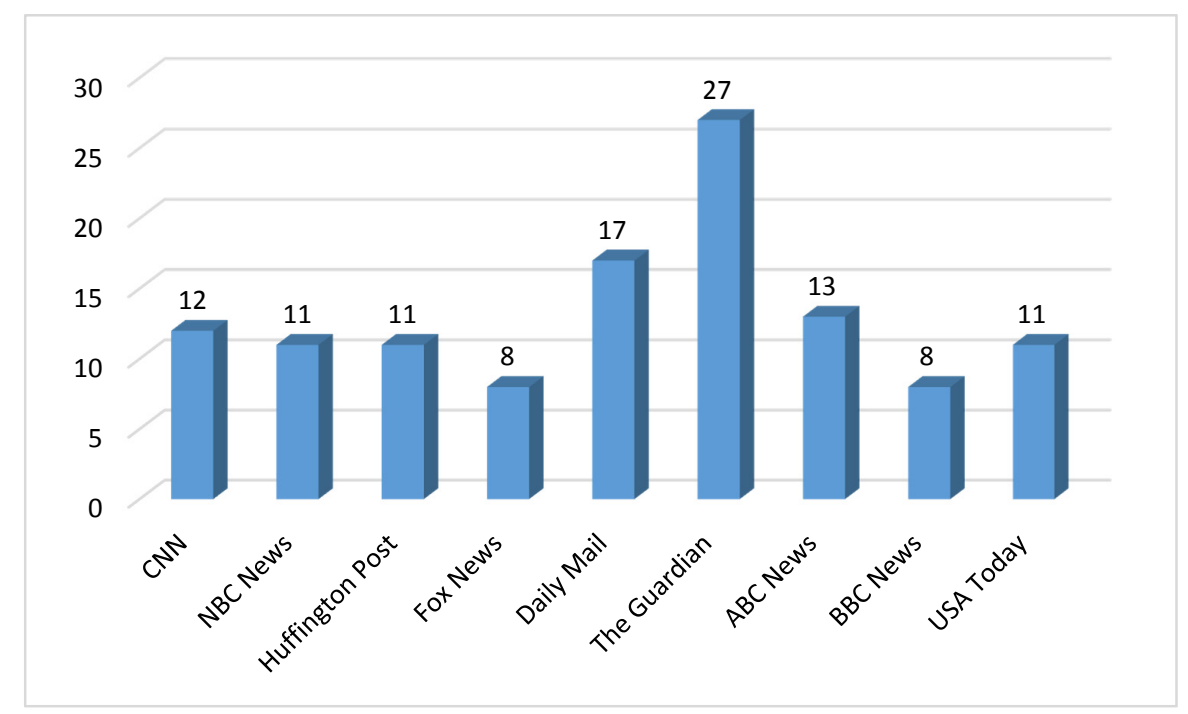

Figure 1. Distribution of articles by news pages.

The development of the articles in the total sample (164 in total) by publication date is illustrated in Figure 2. The topic received more attention in the second half of March (Figure 2). For some reason, the most articles per day were published on 18 March and 3 April.

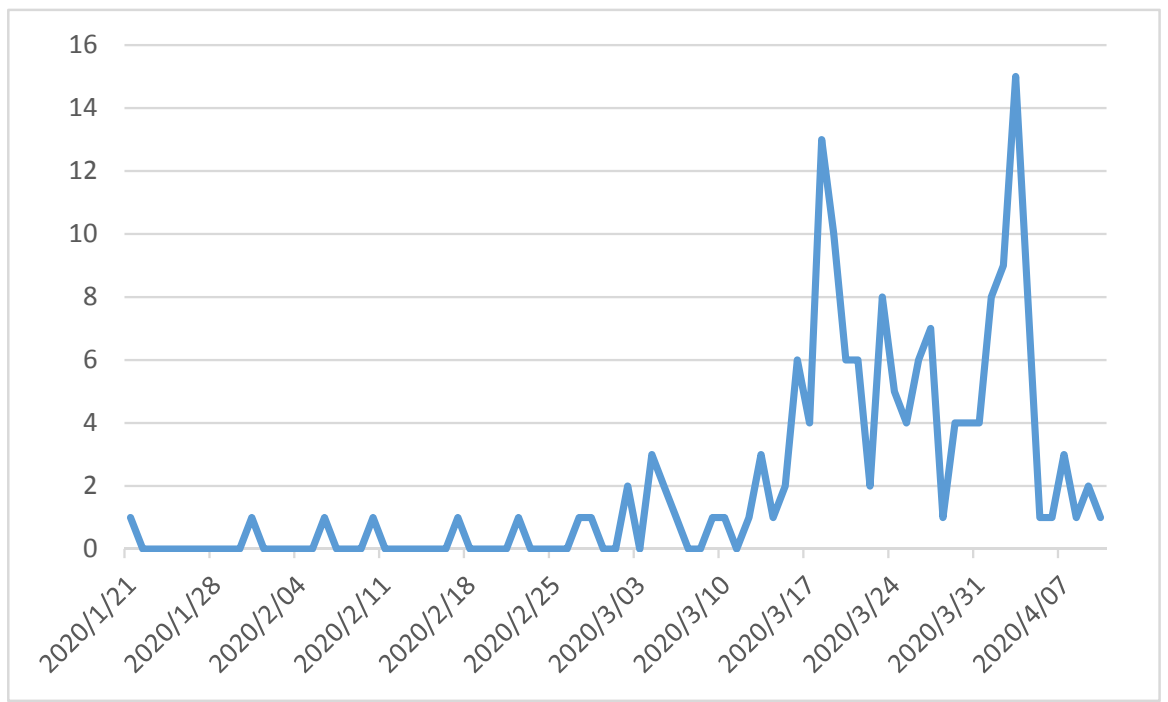

Figure 2. Development of articles by date of publication.

The categorization of the articles was done based on their topic. Finally, we retained only those categories that contained more than five articles. The remaining articles were then grouped into an "other" category. Note that some articles were classified into two categories as they were not specifically focused on one topic. Those articles that cover more than two sub-areas were placed into the "other" category. The distribution of articles is shown in Table 2. 
Table 2. Distribution of articles by category.

\begin{tabular}{cccccc}
\hline & $\begin{array}{c}\text { Demand/Supply } \\
\text { (Number) }\end{array}$ & $\begin{array}{c}\text { Food Safety } \\
\text { (Number) }\end{array}$ & $\begin{array}{c}\text { Food Security } \\
\text { (Number) }\end{array}$ & $\begin{array}{c}\text { Labour } \\
\text { (Number) }\end{array}$ & $\begin{array}{c}\text { Trade and Other } \\
\text { (Number) }\end{array}$ \\
\hline CNN & 4 & 1 & 1 & 0 & 6 \\
\hline NBC News & 6 & 1 & 1 & 1 & 3 \\
\hline Huffington Post & 6 & 4 & 1 & 0 & 0 \\
\hline Fox News & 6 & 2 & 0 & 0 & 1 \\
\hline Daily Mail & 11 & 2 & 2 & 0 & 2 \\
\hline The Guardian & 14 & 0 & 8 & 4 & 6 \\
\hline ABC News & 4 & 1 & 2 & 0 & 6 \\
\hline BBC News & 4 & 0 & 0 & 1 & 3 \\
\hline USA Today & 5 & 2 & 1 & 0 & 3 \\
\hline $\begin{array}{c}\text { Search by keywords } \\
\text { news }\end{array}$ & 10 & 1 & 1 & 13 & 25 \\
\hline Total sample & 70 & 14 & 17 & 19 & 55 \\
\hline
\end{tabular}

It is clear from Table 2 that the vast majority of the articles covered the topic of demand/supply. The news sites involved in the search dealt mostly with food safety and food security, while the websites found during the simple keyword search paid special attention to the effects of the labour market. The frequency of topics by time of publication is shown in Figure 3.

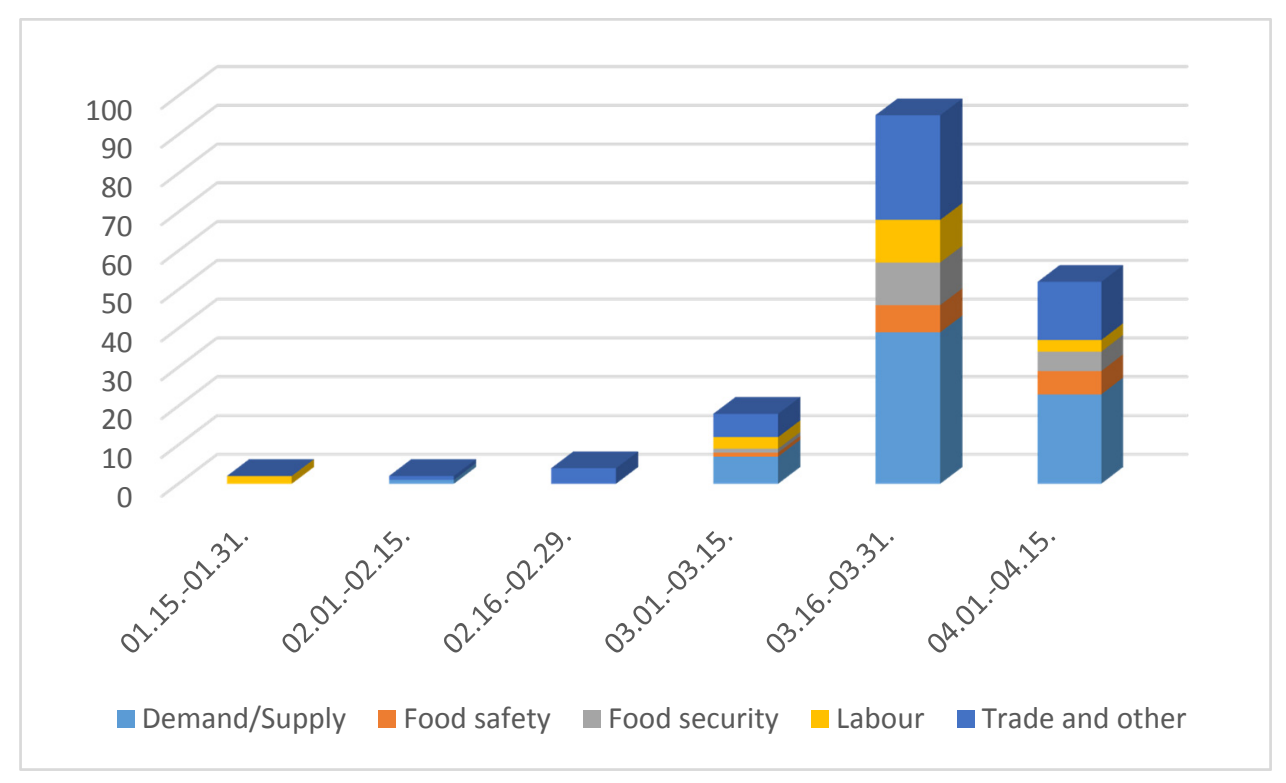

Figure 3. The frequency of topics by publication date.

Figure 3 shows that the demand/supply theme accounted for the largest share in almost all periods. In addition, it can be seen that the number of labour-force-related writings began to decline by April.

The next aspect of the analysis was which countries the articles were written about. During the search of the news websites, we found that this was largely related to where an article was written. A more varied picture is shown based on the results of the search by "keywords + news" (Table 3). It is important to highlight that articles written about more countries (but not globally) were categorized in more places (for example articles about USA and Italy were categorized into "USA" and "Other" groups). 
Table 3. Distribution of articles by target country.

\begin{tabular}{ccccc}
\hline & USA (Number) & UK (Number) & Other (Number) & Global (Number) \\
\hline CNN & 8 & 1 & 2 & 2 \\
\hline NBC News & 7 & 0 & 2 & 2 \\
\hline Huffington Post & 4 & 1 & 3 & 4 \\
\hline Fox News & 6 & 0 & 3 & 1 \\
\hline Daily Mail & 2 & 9 & 7 & 3 \\
\hline The Guardian & 5 & 11 & 4 & 1 \\
\hline ABC News & 8 & 4 & 2 & 3 \\
\hline BBC News & 0 & 6 & 21 & 4 \\
\hline USA Today & 8 & 0 & 45 & 24 \\
\hline $\begin{array}{c}\text { Search by } \\
\text { keywords + news }\end{array}$ & 17 & 6 & 38 & 0 \\
\hline Total sample & 65 & & 21 & 3 \\
\hline
\end{tabular}

Finally, we used a contingency table analysis to examine whether there was an association between the target country (from which the article was written) and the topics. In order to perform the analysis, two groups (USA and Other) were formed according to the target country. The results obtained are shown in Table 4.

Table 4. Contingency table between target country and topics.

\begin{tabular}{|c|c|c|c|c|c|c|}
\hline & $\begin{array}{c}\text { Demand/Supply } \\
\text { (Number) }\end{array}$ & $\begin{array}{l}\text { Food Safety } \\
\text { (Number) }\end{array}$ & $\begin{array}{l}\text { Food Security } \\
\text { (Number) }\end{array}$ & $\begin{array}{c}\text { Labour } \\
\text { (Number) }\end{array}$ & $\begin{array}{l}\text { Trade and Other } \\
\text { (Number) }\end{array}$ & $\begin{array}{c}\text { Total } \\
\text { (Number) }\end{array}$ \\
\hline USA & $\begin{array}{c}27 \\
(-0.1)\end{array}$ & $\begin{array}{c}3 \\
(-1.4)\end{array}$ & $\begin{array}{c}9 \\
(1.3)\end{array}$ & $\begin{array}{c}7 \\
(-0.1)\end{array}$ & $\begin{array}{c}22 \\
(0.2)\end{array}$ & 68 \\
\hline Other & $\begin{array}{c}44 \\
(0.1)\end{array}$ & $\begin{array}{c}11 \\
(1.4)\end{array}$ & $\begin{array}{c}8 \\
(-1.3)\end{array}$ & $\begin{array}{c}12 \\
(0.1)\end{array}$ & $\begin{array}{c}34 \\
(-0.2)\end{array}$ & 109 \\
\hline Total & 71 & 14 & 17 & 19 & 56 & 177 \\
\hline
\end{tabular}

Note: Adjusted residual values are in parentheses.

Based on the value of the chi-square test $\left(\chi^{2}=3.266 ; \mathrm{df}=4 ; p=0.514\right)$, we did not find a significant association between the target country and the topics. This means that, in addition to the United States, various agribusiness-related issues have been addressed in similar proportions in other countries.

\section{Discussion}

It is evident that the global pandemic has affected agriculture in many ways. The major problems analysed from the selected newspaper articles are shown in Figure 4. This section aims to provide a detailed discussion of the major problems identified.

\subsection{Supply-Related Impacts}

One of the major concerns of the newspaper articles was related to food supply. Many articles expressed concern that farmers would stop producing because of the pandemic (as they get sick) and less food will be available, if at all, at higher prices [2]. This is probably the first and most common agriculture-related issue raised in times of a global crisis. Another concern regarding food supply was related to the perishability of the products - a farmer is on strict planting and harvesting schedule and cannot modify production at will. Many farmers face such problems as additional days of storage make their products worthless. Springtime is a critical planting and harvesting time for many farmers around the globe, and the pandemic has made agricultural markets even more unpredictable. Moreover, 
disruptions in the accessibility of inputs like mineral fertilisers also added to the uncertainty of the situation [3].

Crisis gardening, which is not new in human history, is now proliferating, as some articles argue, as more and more people start to grow food on their own in their backyards [4]. This might alleviate the instant pressure to buy food and, of course, has many more positive effects besides this (better understanding of the food system, fresh and healthy food production, etc.).

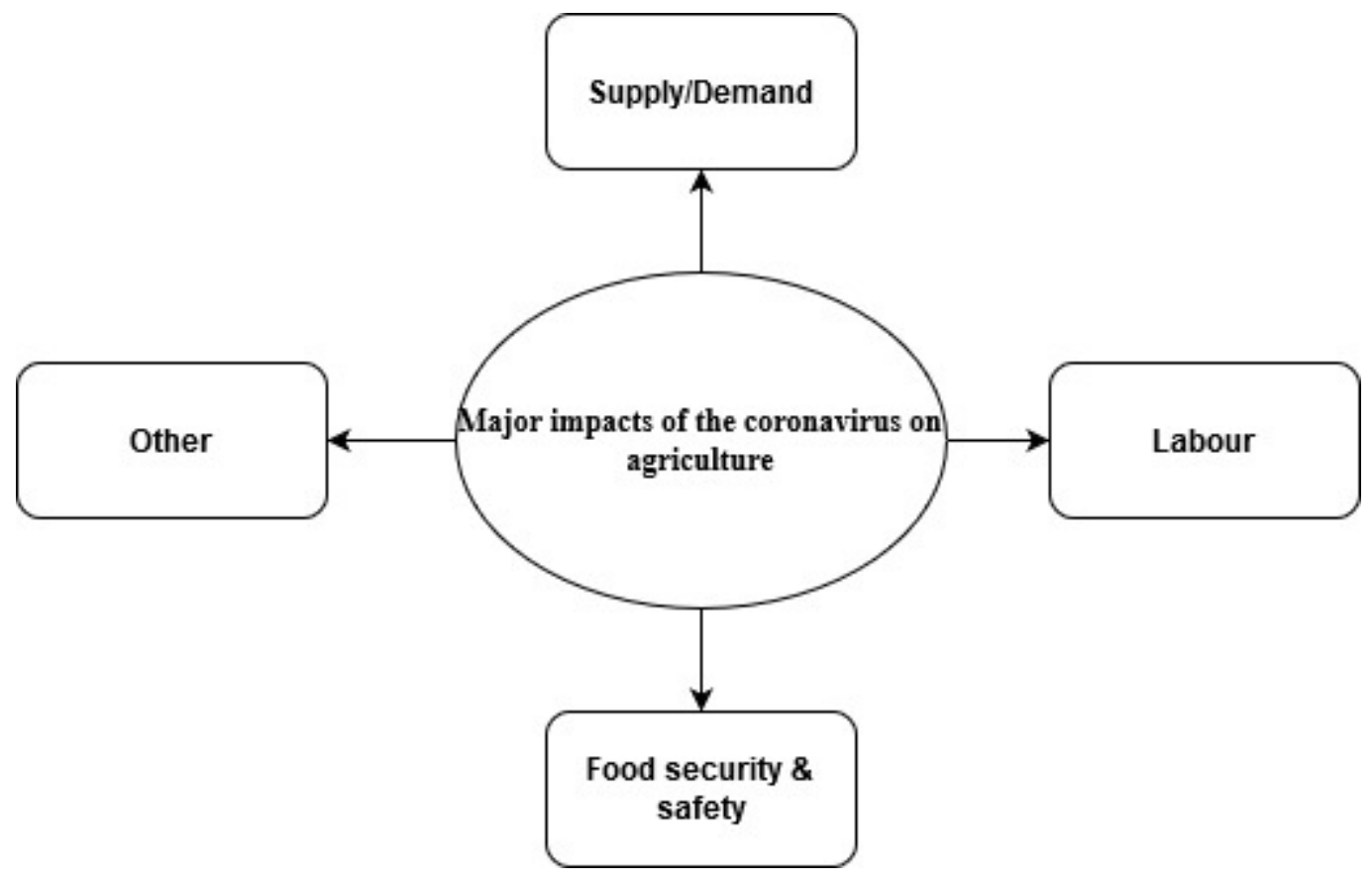

Figure 4. Major impacts of the coronavirus on agriculture.

\subsection{Demand-Related Impacts}

As to demand-related impacts, probably the most important impact described by the articles was panic shopping and stockpiling. In the fear of being locked down for a longer period, people have started to buy up huge stocks of durable food in a relatively short time period, thereby causing difficulties for supermarkets [5]. The most mentioned food and produce include beans, rice, frozen (UHT) milk, bread, eggs, dried food, nuts and canned food, as well as various prepared and processed foodstuffs.

Seasonal effects made this even worse, as was evident in many places with eggs around Easter. Panic food buying could also cause world food inflation to soar despite ample supplies of staple foods, as some articles and experts warn [6,7]. This is not a supply issue; this is a serious behavioural change. Many governments have echoed these words recently in trying to counteract panic buying behaviour [8]. At the other end, however, many articles show concern for farmers facing heavy losses due to the pandemic as their products are not in high demand [9]. What can flower producers, for instance, do with their beautiful roses?

There is, however, a duality in demand-related impacts. On the one hand, out-of-home food consumption was affected the most as restaurants and bars were closed. On the other hand, in-home food consumption had some positive substitution effects (home cooking), though in-home consumption can also be affected negatively in the long run with the rise of income instability [10].

\subsection{Labour-Related Impacts}

Another major effect of the pandemic highlighted in the articles was agricultural labour. If farmers cannot find enough workers, a part of their produce will be lost, and hence, consumers will face higher prices [11]. As the world is globalised, this also means less or more costly imports for countries 
depending on external food supplies. As people are instructed and expected to stay at home, the whole supply chain can experience disruptions in addition to those impacting the normal farming processes. Critical employees along the supply chain like truck drivers or ship dock workers can get sick, quarantined or forced to stay at home, enlarging the initial impacts [12]. Extended worktimes and pressure can also put the physical and mental health of labour at risk, possibly leading to further crew shortages [13]. Short timeframes and the perishability of agricultural produce also put serious constraints on non-agricultural labour.

Moreover, as the virus limits the free flow of labour, farmers are also worried that they will not be able to hire enough workers, particularly for planting and harvesting [14]. Agriculture is a sector that typically hires a large number of part-time or seasonal workers, and the virus clearly causes a scarcity of farm labour force. Furthermore, a significant amount of such labour is comprised of migrant workers coming from countries far away who cannot be substituted in the short term [15]. This situation is especially difficult for the UK, which has just ended its long-lasting Brexit process that had also created similar problems [10]. However, this situation might be solved in the short term as workers losing their jobs in other sectors might end up working for agriculture, even if they are not well qualified. Of course, inefficiency can slow down farm operations. Moreover, the physical and difficult nature of agricultural work will most likely "protect" the sector from mass labour inflows. It was also interesting to read a few articles on the demand growth for drones and unmanned vehicles, trying to substitute the human workforce [16].

Some articles mention that farm workers fear being infected by the virus, but at the same time fear losing their jobs and salaries. Farmer Unions generally started to call growers for proactive steps so that agricultural workers can feel safe and comfortable in preventing the spread of the virus-labour rights are now also on the table [17].

\subsection{Food Security and Safety Impacts}

Food security issues are also covered by certain articles based on the simple fact that approximately a third of the global population is on lockdown. In the first months of the pandemic, many target measures were taken by China and then Italy to maintain food security [18].

One of the issues covered here is related to the shutting down of schools. As school lunch programmes all over the world provide low-cost and free lunches to millions of children, many parents face now real challenges to feed their hungry children [19]. Another current issue of concern is how to provide food security for vulnerable residents who cannot walk into a grocery store and have no internet access or knowledge of how the system works. The food security of homeless people is also covered by the media as a problem to be faced during pandemic times. Others also warn that poor households can easily run out of food. Many articles mention the revisited role of food banks and how they treat new challenges of food security listed above [20].

The Food and Agriculture Organization (FAO) is suggesting specific strategies like expanding emergency food assistance programs and providing immediate assistance to smallholders by focusing on logistics and boosting e-commerce. These strategies are partly based on the FAO's previous experience with food-related crises like Ebola in 2014 and the global food crisis in 2008 [18].

Newspaper articles have been written on food safety issues as well. The basic question is whether careful shopping, takeout, or order delivery is the safest mode of food purchase. As there is no evidence so far that COVID-19 is foodborne or foodservice-driven, food service is not likely driving the epidemic. Of course, food packages can also be virus transmitters, but as most articles suggest, the chances that these could carry the virus are very low. However, there is more risk of contamination when a worker is sick-this situation can be handled by strict employee health policies. Virus contamination can also come through delivery services, but many of these services are touch-free and use cashless transactions [21].

The risk is probably the highest in crowded supermarkets, and many articles argue for proper precautionary measures-this topic, however, leads far away from economic impacts. How to eat 
healthy food during the pandemic is also an issue mentioned frequently even in the economic news, which additionally leads very far from our main story. One interesting dilemma, however, regarding the latter is whether the coronavirus will make us fitter or fatter, depending on how we manage everyday life during the pandemic [22].

Another concern related to food safety is the issue of transmission. It is not fully evident whether the virus can be transmitted from humans to animals or vice versa. Scientists and researchers are now seeking more evidence and information on this topic [23].

\subsection{Trade and Other Impacts}

On the one hand, the coronavirus seems to help liberalising agri-food trade. China, for instance, has already announced a significant reduction of tariffs for US-based products, thereby continuing to step back from a years-long trade war hurting both economies [24]. Products concerned include agricultural goods like soybeans, pork, cotton and wheat. Although coming from a different sector, masks and gloves are also of critical importance for agriculture as keys to slow down the pandemic locally.

On the other hand, as is common in times of global crisis, some countries have started to close their borders in the fear of decreased domestic supplies. Kazakhstan, one of the major wheat exporters of the world, has temporarily banned shipments of some key staple foods due to such worries. The mass spread of such protectionist movements can seriously deepen current supply problems [25].

Several disruptions that emerge in global trade flows of agricultural and food products are also due to logistics problems. Many consumers have already experienced the blow of this effect when faced with empty shelves on supermarket stores, caused by bottlenecks in global food supply chains. This is especially true for products coming entirely from abroad due to climatic reasons (coffee, bananas, etc.). Travel restrictions make it especially hard for farmers, wholesalers and retailers to sell their products, many of which are coming from abroad. Supermarkets which have generally became accustomed to just-in-time deliveries, are now faced with increased demand and panic buying. They also face a significant change in volumes as people now cook and eat more at home compared to the pre-pandemic period [10].

Another interesting angle of the pandemic is the rapid increase of e-commerce, as reported by some articles. At the time of writing, direct sales from farmers to consumers were on the rise, together with the increase of household food consumption [26,27].

\section{Conclusions}

Everyone around the world likely knows that agriculture is one of the most unpredictable sectors. This principle seems to become even truer now. Farmers, food processors, retailers and virtually all stakeholders of the sector now wonder what is coming next. How much should they produce to meet summer demand? What should they do with the stocks and losses? How will family farmers survive? How much should they sell and to whom?

Various scenarios are envisaged in the surveyed articles, from fast recovery to a long-lasting crisis. Everything depends on the length of the pandemic. Most governments of the world have now launched some ad-hoc measures as part of a "fire-brigade policy-making" to tackle the effects of the initial shock. However, these first reactions led to stockpiling behaviour at the household level. If the pandemic lasts for many more months, these efforts will surely not be enough. Medium- and long-term "economy survival" programmes are about to be elaborated to manage long-term effects, including those impacting agriculture.

It is evident that the COVID-19 pandemic turned the world upside down, including agriculture. Much more work is now needed from various scientists working in different fields to analyse the effects. In the current situation when long-term data are not yet available, this conceptual paper might serve as a background for future research in highlighting the fields of global interest in agriculture and related sectors. 
As a limitation of the study, note that our analyses are based on English-language results only, which, on the one hand is understandable and, on the other hand, poses some bias. It would have been an endless exercise to investigate articles in all languages of the world. Although local issues can also be important, we think that all major global issues raised in the period analysed are covered by our search and results.

Author Contributions: Conceptualization, A.J., P.C. and P.B.; methodology, A.J., P.C. and P.B.; software, A.J., P.C. and P.B.; validation, A.J., P.C. and P.B.; formal analysis, A.J.; investigation, A.J., P.C. and P.B.; resources, P.B.; data curation, A.J., P.C. and P.B.; writing-original draft preparation, A.J., P.C. and P.B.; writing-review and editing, A.J., P.C. and P.B.; visualization, A.J.; supervision, A.J., P.C. and P.B.; funding acquisition, P.B. All authors have read and agreed to the published version of the manuscript.

Funding: The publication is supported by the EU-funded Hungarian grant EFOP-3.6.3.-VEKOP-16-2017-00007 for the project entitled "From Talent to Young Researchers"-Supporting the Career-developing Activities of Researchers in Higher Education.

Conflicts of Interest: The authors declare no conflicts of interest.

\section{References}

1. Available online: http://www.ebizmba.com/articles/news-websites (accessed on 1 April 2020).

2. What Happens to Our Food Supply If American Farmers Can't Farm? CNN News. Available online: https://edition.cnn.com/2020/03/31/business/food-supply-disruption-coronavirus-us/index.html (accessed on 3 April 2020).

3. Farmworkers 'Harvesting America's Food Supply' Amid Coronavirus Pandemic Fight for Safety. NBC News. Available online: https://www.nbcnews.com/news/latino/farmworkers-harvesting-america-s-foodsupply-amid-coronavirus-pandemic-fight-n1173241 (accessed on 4 April 2020).

4. How The Coronavirus Pandemic Has Led to A Boom in Crisis Gardening. Huffington Post. Available online: https://www.huffpost.com/entry/seeds-crisis-gardening-coronavirus-food_n_ 5e85eca0c5b6f55ebf492212 (accessed on 4 April 2020).

5. Will Fears of Coronavirus Change Demand for Farm Goods? Daily Democrat. Available online: https: //www.dailydemocrat.com/2020/03/11/will-fears-of-coronavirus-change-demand-for-farm-goods/ (accessed on 2 April 2020).

6. What the Pandemic Means for Your Easter Food Shopping. CNN News. Available online: https:/edition. cnn.com/2020/04/01/business/easter-shopping-coronavirus/index.html (accessed on 5 April 2020).

7. Egg Prices Are Skyrocketing because of Coronavirus Panic Shopping. CNN News. Available online: https://edition.cnn.com/2020/03/25/business/egg-prices-supermarkets-coronavirus/index.html (accessed on 5 April 2020).

8. Coronavirus: New Measures Aim to Safeguard Food Production, Help Farmers. Irish Times. Available online: https://www.irishtimes.com/news/health/coronavirus-new-measures-aim-to-safeguardfood-production-help-farmers-1.4203418 (accessed on 1 April 2020).

9. How the Coronavirus Could Impact Dairy Producers. Available online: https://www.agriculture.com/news/ livestock/how-the-coronavirus-could-impact-dairy-producers (accessed on 1 April 2020).

10. Phillipson, J.; Gorton, M.; Turner, R.; Shucksmith, M.; Aitken-McDermott, K.; Areal, F.; Cowie, P.; Hubbard, C.; Maioli, S.; McAreavey, R.; et al. Covid-19 and rural economies. In Briefing Note Prepared by Staff of the Centre for Rural Economy and Rural Enterprise; Newcastle University: Newcastle, UK, 2020.

11. Seasonal Workers, CAP and COVID-19, Farm to Fork. Available online: https://www.euractiv.com/section/ agriculture-food/news/seasonal-workers-cap-and-covid-19-farm-to-fork/ (accessed on 6 April 2020).

12. Coronavirus Threat to EU Farm Seasonal Workers. Available online: https://euobserver.com/coronavirus/ 147890 (accessed on 8 April 2020).

13. Coronavirus Stress-Tests the Food Supply Network. Available online: https://www.politico.com/newsletters/ morning-agriculture/2020/03/18/coronavirus-stress-tests-the-food-supply-network-786186 (accessed on 10 April 2020).

14. European Commission. Short-Term Outlook for EU Agricultural Markets in 2020; European Commission: Brussels, Belgium, 2020; Volume 26. 
15. Coronavirus Fears for Italy's Exploited African Fruit Pickers. Available online: https://www.aljazeera.com/ indepth/features/coronavirus-fears-italy-exploited-african-fruit-pickers-200318154351889.html (accessed on 10 April 2020).

16. Chinese Agriculture Drone Makers See Demand Rise Amid Coronavirus Outbreak. NBC News. Available online: https://www.cnbc.com/2020/03/10/chinese-agriculture-drone-makers-see-demand-riseamid-coronavirus-outbreak.html (accessed on 6 April 2020).

17. COVID-19 Threatens Food Supply Chain as Farms Worry about Workers Falling Ill. Available online: https://www.npr.org/2020/03/18/816644358/covid-19-threatens-food-supply-chain-as-farms-worryabout-workers-falling-ill? $\mathrm{t}=1585975550970$ (accessed on 7 April 2020).

18. Coronavirus Disease 2019 (COVID-19). Addressing the Impacts of COVID-19 in Food Crises. Available online: http://www.fao.org/emergencies/appeals/detail/en/c/1270012/fbdfb (accessed on 9 April 2020).

19. Coronavirus: 300 Million Children to Miss School Meals Amid Shutdowns. The Guardian. Available online: https://www.theguardian.com/world/2020/mar/21/coronavirus-300-million-children-to-miss-schoolmeals-amid-shutdowns (accessed on 4 April 2020).

20. Morrisons Gives Food Banks £10m During Coronavirus Outbreak. The Guardian. Available online: https://www.theguardian.com/world/2020/mar/30/morrisons-gives-food-banks-10m-during-coronavirusoutbreak (accessed on 5 April 2020).

21. Coronavirus Grocery List: What to Buy in Case of Self-Quarantine. NBC News. Available online: https://www.nbcnewyork.com/news/national-international/coronavirus-grocery-list-what-itemsyou-need-to-buy-in-case-of-self-quarantine/2313773/ (accessed on 9 April 2020).

22. Coronavirus Will Make us FATTER: People Will Exercise Less because of Lockdown and Eat More due to Stress and Stockpiled Food, Experts Warn. Daily Mail. Available online: https://www.dailymail.co.uk/news/ article-8183901/How-coronavirus-lockdown-make-fatter.html (accessed on 4 April 2020).

23. Galanakis, C.M. The Food Systems in the Era of the Coronavirus (COVID-19) Pandemic Crisis. Foods 2020, 9 , 523. [CrossRef] [PubMed]

24. The Coronavirus Will Delay Agricultural Export Surges Promised in Trade Deal with China. Available online: http://theconversation.com/the-coronavirus-will-delay-agricultural-export-surges-promised-intrade-deal-with-china-132227 (accessed on 10 April 2020).

25. Torero, M.C. COVID-19 and the Risk to Food Supply Chains: How to Respond? FAO: Roma, Italy, 2020.

26. Coronavirus: How can I Shop or Get Deliveries and Takeaways Safely? BBC News. Available online: https://www.bbc.com/news/science-environment-52040138 (accessed on 9 April 2020).

27. Haas, R.; Imami, D.; Miftari, I.; Ymerie, P.; Grunert, K. How do Kosovar and Albanian consumers perceive food quality and safety in the dairy sector? Studies Agric. Econ. 2019, 121, 119-126. [CrossRef]

(C) 2020 by the authors. Licensee MDPI, Basel, Switzerland. This article is an open access article distributed under the terms and conditions of the Creative Commons Attribution (CC BY) license (http://creativecommons.org/licenses/by/4.0/). 